\title{
Evolution and development of interhemispheric connections in the vertebrate forebrain
}

\author{
Rodrigo Suárez ${ }^{1}$, Ilan Gobius ${ }^{1}$ and Linda J. Richards ${ }^{1,2 *}$ \\ 1 Queensland Brain Institute, The University of Queensland, Brisbane, QLD, Australia \\ ${ }^{2}$ School of Biomedical Sciences, The University of Queensland, Brisbane, QLD, Australia
}

\section{Edited by:}

Roberto Lent, Federal University of Rio de Janeiro, Brazil

Reviewed by:

Giorgio Innocenti, Karolinska Institutet, Sweden

Fernanda Tovar-Moll, Federal University of Rio de Janeiro and D'Or Institute for Research and Education, Brazil

\section{${ }^{*}$ Correspondence:}

Rodrigo Suárez and Linda J. Richards, Queensland Brain Institute, The University of

Queensland, Building \#79, Brisbane, QLD 4072, Australia

e-mail: rsuarezsaa@gmail.com; richards@uq.edu.au
Axonal connections between the left and right sides of the brain are crucial for bilateral integration of lateralized sensory, motor, and associative functions. Throughout vertebrate species, forebrain commissures share a conserved developmental plan, a similar position relative to each other within the brain and similar patterns of connectivity. However, major events in the evolution of the vertebrate brain, such as the expansion of the telencephalon in tetrapods and the origin of the six-layered isocortex in mammals, resulted in the emergence and diversification of new commissural routes. These new interhemispheric connections include the pallial commissure, which appeared in the ancestors of tetrapods and connects the left and right sides of the medial pallium (hippocampus in mammals), and the corpus callosum, which is exclusive to eutherian (placental) mammals and connects both isocortical hemispheres. A comparative analysis of commissural systems in vertebrates reveals that the emergence of new commissural routes may have involved co-option of developmental mechanisms and anatomical substrates of preexistent commissural pathways. One of the embryonic regions of interest for studying these processes is the commissural plate, a portion of the early telencephalic midline that provides molecular specification and a cellular scaffold for the development of commissural axons. Further investigations into these embryonic processes in carefully selected species will provide insights not only into the mechanisms driving commissural evolution, but also regarding more general biological problems such as the role of developmental plasticity in evolutionary change.

Keywords: anterior commissure, axon guidance, commissural plate, comparative neuroanatomy, corpus callosum, hippocampal commissure

\section{INTRODUCTION}

In animals with bilateral symmetry, integration between the left and right sides of the body is crucial for processing lateralized sensory-motor functions. This is accomplished by axonal connections between the two sides of the nervous system, known as commissures. Commissural systems are present throughout vertebrate and invertebrate species (Arendt et al., 2008; Semmler et al., 2010), and similar mechanisms of axon guidance across the midline suggest the conservation of these developmental processes from a common bilaterian ancestor (Brose et al., 1999; Hirth and Reichert, 2007; Round and Stein, 2007; Evans and Bashaw, 2012).

During vertebrate evolution, several brain developmental events have been conserved from lampreys to humans, possibly explaining the broad anatomical similarity of adult forebrain commissures across species. However, diversification of the telencephalic commissures in mammals, including new axonal routes in diprotodont marsupials and the origin of the corpus callosum in eutherian (placental) mammals, illustrate natural examples of diversity in the developmental mechanisms involved in commissure formation.

Development of commissures entails a sequence of events involving morphogenic area patterning, cell-type specification, neuron-glia interactions, production and reception of guidance cues, axonal growth and navigation, and activity-dependent establishment of contralateral connections. In humans, disorders affecting these events at any stage can prevent the normal formation of the commissures, resulting in mild to severe sensorymotor and cognitive conditions (for specific review, see Paul et al., 2007). Therefore, understanding the fundamental processes directing commissure formation remains an important challenge for neuroscientists. One way to address this includes adopting an evolutionary-developmental perspective, i.e., to compare experimental data on commissure development and function from different species while considering the phylogenetic relationships between them. This allows the categorization of developmental processes as conserved or derived within lineages, thus outlining critical features of normal brain development. Using this approach, here we examine anatomical and developmental features of forebrain commissures in vertebrates to gain insights into the development and evolution of the corpus callosum, the largest axonal tract in the human brain.

\section{CONSERVATION OF A DEVELOPMENTAL PLAN IN THE VERTEBRATE BRAIN}

The origin and diversification of forebrain commissures in vertebrates is likely to be related to a general developmental plan 
upon which evolution may act. Such is the case of the early molecular determination of midline forebrain territories, which is strikingly similar across vertebrate species. It involves the patterned expression of morphogens in defined regions that, through their interaction in three-dimensional space, specify cellular fate and commissure formation. After closure of the neural tube, patterning centers at the dorsal and ventral midline establish gradient territories through the expression of the diffusible morphogens Wnt/BMP and sonic hedgehog (Shh), respectively. At the rostral tip of the prosencephalon, fibroblast growth factor (Fgf) proteins are expressed in a region known as the anterior neural ridge, which then becomes the commissural plate, a structure through which the telencephalic commissures cross the midline (Figure 1A). Fgfs are also expressed more caudally along the dorsal midline, at the border between the presumptive prethalamus and dorsal thalamus, in a patterning region known as the zona limitans intrathalamica, which is characterized by a narrow band of Shh expression that forms a continuum with ventral Shh expression in the prechordal plate. The isthmic organizer, another patterning center widely conserved in vertebrates, is located at the border between the midbrain and hindbrain and is characterized by a narrow ring of Fgf and Wnt/Bmp expression extending dorsoventrally (Figure 1A). This general organization is largely maintained across vertebrate taxa from lampreys to mammals (Walshe and Mason, 2003; Buckles et al., 2004; Wilson and Houart, 2004; Tole et al., 2006; O’Leary et al., 2007; Rétaux and Kano, 2010; Rash and Grove, 2011; Sugahara et al., 2013), and therefore represents an important landmark in brain development. Moreover, the relative positions and expression profiles of these patterning centers are similarly present in some nonvertebrate lineages, such as the hemichordate acorn worm, suggesting the ancient conservation of a morphogenic program since early deuterostomes (Pani et al., 2012). Notably, these early systems of protein gradient production not only instruct overall brain area patterning (Shimogori and Grove, 2005; O'Leary et al., 2007; Assimacopoulos et al., 2012), but also serve as guidance cues for growing axons (Charron et al., 2003; Walshe and Mason, 2003; Tole et al., 2006; Zou and Lyuksyutova, 2007; Toyama et al., 2013). Similarly, as described in more detail below, the spatial locations of these organizing centers broadly coincide with regions of commissural axon crossing, such as the post-optic commissure and posterior commissure, which are the first commissures to form during vertebrate development (Figure 1B; Herrick, 1937; Kuratani et al., 1998; Doldan et al., 2000; Barreiro-Iglesias et al., 2008). Thus, the conservation of these early mechanisms of forebrain development across vertebrate species suggest that area patterning and cell-specification functions may have been coopted for axon guidance and commissural circuit formation. Therefore, the emergence of non-disruptive variations in these processes may underlie the evolution of commissural diversity.

\section{CONSERVED COMMISSURAL PATHWAYS IN EARLY VERTEBRATES}

To examine commissural diversity and evolution, we will first refer to the anatomical organization of forebrain commissures in early-branched vertebrates. A gross comparison of the brain of the jawless hagfish and lampreys, cartilaginous sharks, and

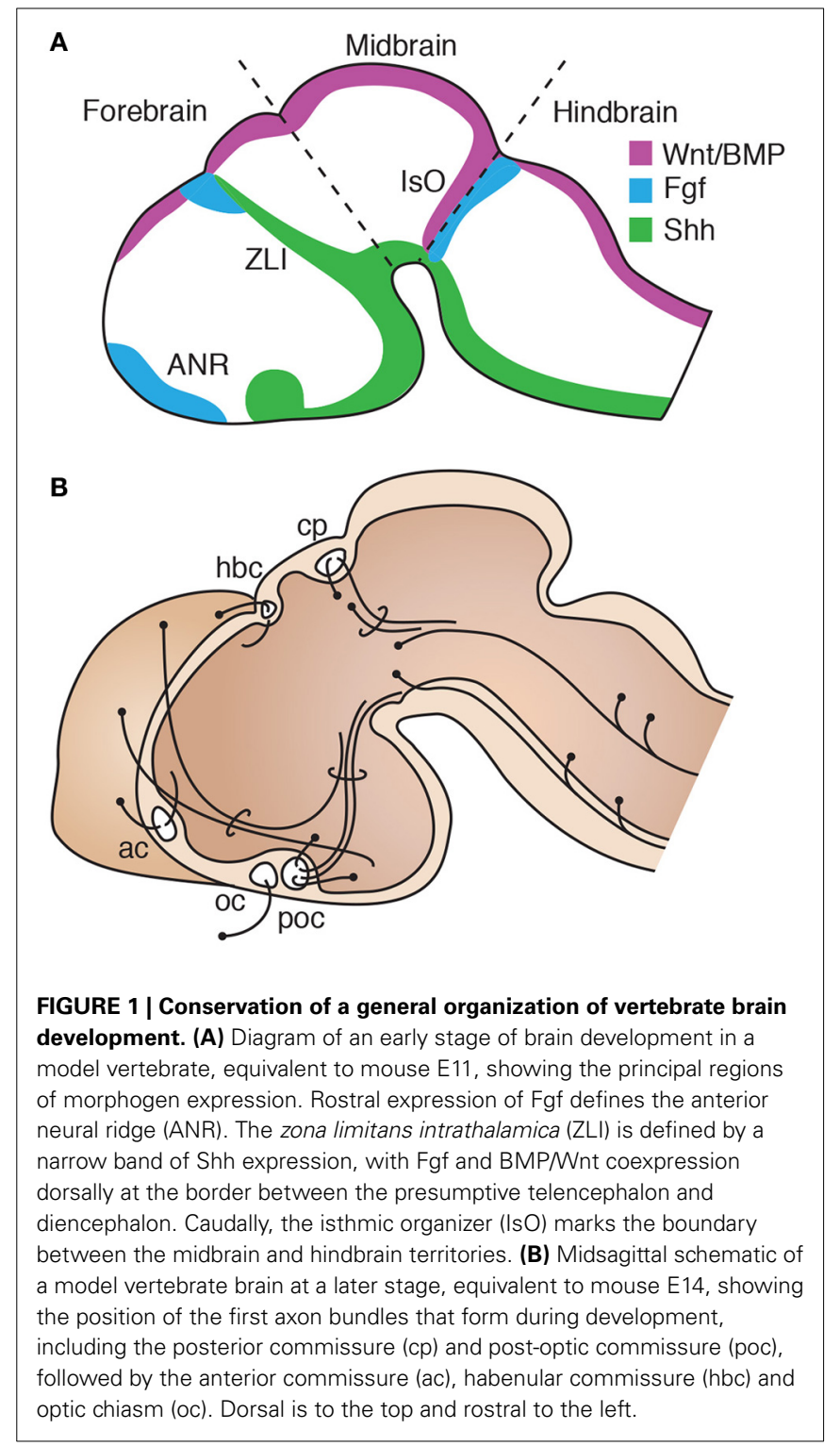

teleost fish, reveals overall similarities in the relative position of commissural connections within the brain (Figure 2A). Briefly, at the caudal-most extent of the forebrain lies the posterior commissure (cp; Figure 2A, yellow), which connects dorsal regions of the diencephalon (i.e., dorsal thalamus) and mesencephalon (i.e., pretectum and optic tectum) (Nieuwenhuys and Nicholson, 1998; Wicht and Nieuwenhuys, 1998). In the basal diencephalon, two regions of midline axon crossing are found throughout vertebrates: the postoptic commissure (poc; Figure 2, light green), and optic chiasm (oc; Figure 2, gray). The postoptic commissure carries axons bilaterally connecting the preoptic area and the hypothalamus, as well as telencephalic and thalamic fibers projecting to the hypothalamic region (Nieuwenhuys and Nicholson, 1998; Smeets, 1998; Wicht and Nieuwenhuys, 1998). In all vertebrates, axons from retinal ganglion cells decussate, at least partially, at the optic chiasm to terminate in contralateral diencephalic (lateral thalamus, hypothalamus) and mesencephalic 
A
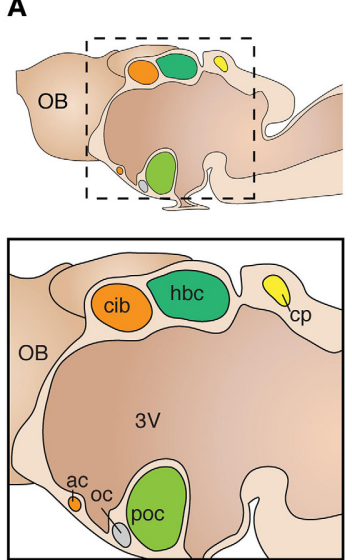

Hagfish
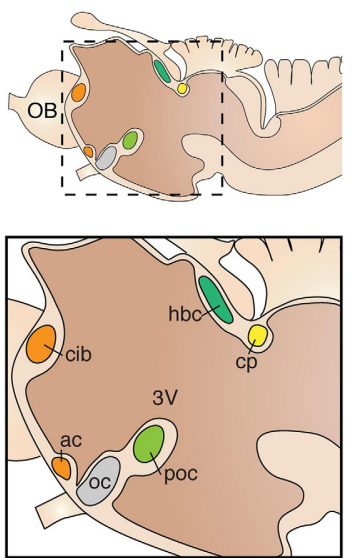

Lamprey
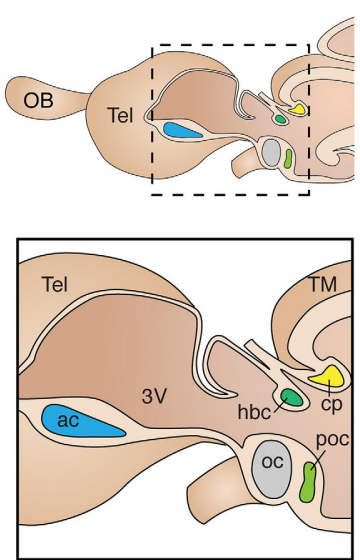

Shark
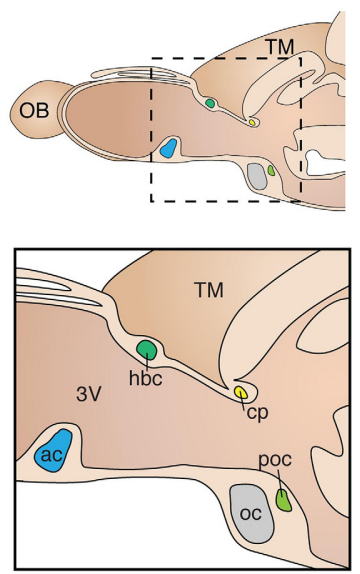

Teleost

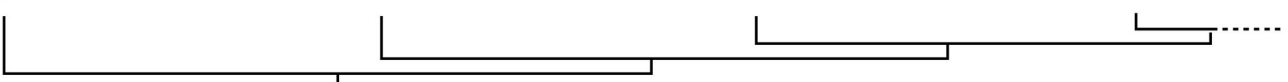

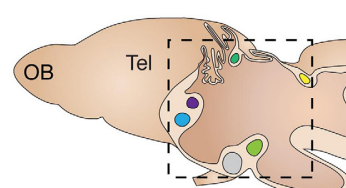

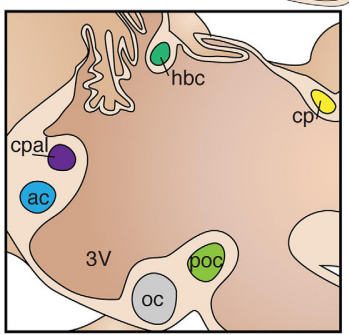

Frog
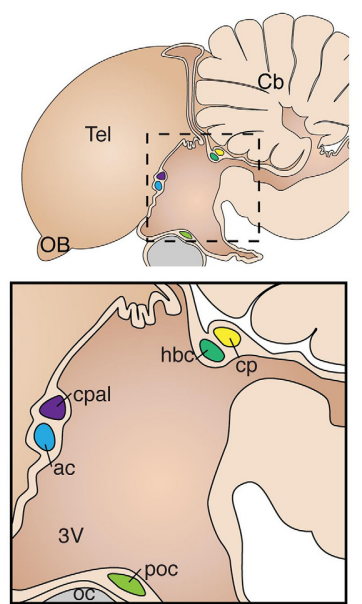

Pigeon
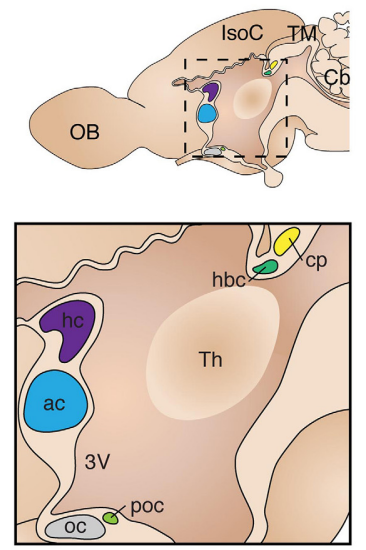

Opossum

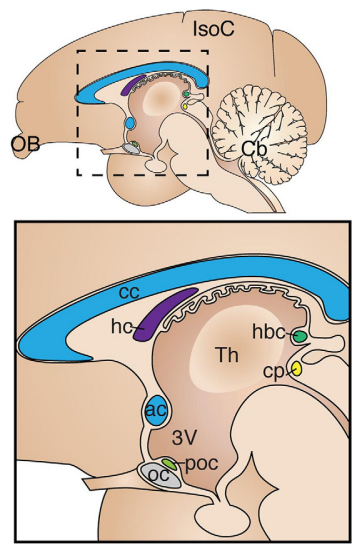

Monkey

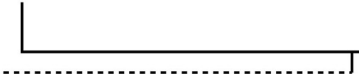

FIGURE 2 | Conservation of commissural systems across adult vertebrate species. (A) Commissures in non-tetrapod species. Note the conserved position of commissures relative to each other within and between species, commissures are color-coded according to homology hypotheses. The commissura interbulbaris (cib) and anterior commissure (ac) of lampreys and hagfish are depicted here with a unique color (orange) to indicate the uncertainty of definitive homology with other vertebrates. (B) Tetrapods are characterized by the evolution of a distinct pallial commissure (cpal) in close dorsal proximity with the anterior commissure. The mammalian homolog of the pallial commissure is known as hippocampal commissure (hc). The corpus callosum (cc) is an evolutionary innovation of placental mammals, located dorsal to the hippocampal commissure. Phylogenetic relationships between species are depicted with dendrograms below species name. $3 \mathrm{~V}$, third ventricle; $\mathrm{Cb}$, cerebellum; $\mathrm{cp}$, posterior commissure; hbc, habenular commissure; IsoC, isocortex; $\mathrm{OB}$, olfactory bulb; oc, optic chiasm; poc, post-optic commissure; Tel, telencephalon; Th, thalamus; TM, tectum mesencephali. (pretectum, tectum) targets. However, as axons forming the optic tract decussate en route to their central targets, without reciprocally connecting bilateral regions, the optic chiasm is not considered a proper commissure. Along the roof of the midline, immediately rostral to the posterior commissure, lies the habenular commissure (hbc; Figure 2A, green), which is prominent in agnathans as compared to other vertebrates (Wicht and Northcutt, 1992). The habenular commissure connects the epithalamus bilaterally, and also contains axons originating from the olfactory bulbs and medial pallium (olfacto-habenularis tract) that terminate contralaterally in pallial, subpallial and diencephalic targets (Northcutt and Puzdrowski, 1988; Polenova and Vesselkin, 1993). The largest commissure in the telencephalon of agnathans is the commissura interbulbaris (cib, Figure 2A, orange). It carries fibers from the olfactory bulbs and pallium, thus resembling the rostral component of the habenular commissure. In fact, the commissura interbulbaris and habenular commissure are located in close proximity to each other in hagfish, and it is hard to distinguish fibers crossing through one or the other commissure (Wicht and Northcutt, 1992, 1998; 
Wicht and Nieuwenhuys, 1998). In contrast, lampreys have a relatively smaller commissura interbulbaris, located more rostral to the habenular commissure than hagfishes (Figure 1A; Northcutt and Puzdrowski, 1988; Polenova and Vesselkin, 1993; Nieuwenhuys and Nicholson, 1998; Pombal et al., 2009). This difference may relate to the fact that while hagfish undergo direct development with olfactory-guided swimming occurring throughout ontogeny, lampreys spend several years as a sessile larva buried in mud, with olfactory behaviors becoming active only during their brief adulthood. Thus, the seemingly derived behavioral and neuroanatomical features of extant agnathans makes it difficult to formulate hypotheses regarding homology of their telencephalic commissural circuits with those of other vertebrates (see Table 1).

At the rostral-most extent of the midline lies the anterior commissure, which in agnathans connect mostly the olfactory bulbs and septum with their contralateral homotopic structures, as well as with hypothalamic targets (Nieuwenhuys and Nicholson, 1998; Wicht and Nieuwenhuys, 1998). Similarly, in cartilaginous fish such as sharks and rays, the anterior commissure carries axons connecting the olfactory bulbs bilaterally, as well as with the septum and striatum (Smeets, 1983, 1998; Yáñez et al., 2011). Interestingly, secondary olfactory axons of cartilaginous and bony fish decussate not only through the anterior commissure, but also through the habenular and postoptic commissures (Smeets, 1998; Northcutt, 2011; Yáñez et al., 2011), suggesting that decussating axons from a single region may cross the midline using more than one commissural route. Whether the medial pallium of sharks and rays connects to contralateral homotopic regions through any of these commissures is not fully established. However, a general pattern of telencephalic connections through the anterior commissure linking olfactory, pallial and subpallial structures is also observed in ray-finned bony fish (Table 1; Folgueira et al., 2004; Northcutt, 2006, 2011). Ray-finned fish are characterized by a developmental eversion of the telencephalon, which contrasts with the evagination of the telencephalic vesicles observed in all other vertebrates, where the homologs of the medial pallium develop into the lateral-most part of the telencephalon (for specific reviews, see Meek and Nieuwenhuys, 1998; Northcutt, 2008; Nieuwenhuys, 2009). This telencephalic arrangement may have prevented the evolution of a defined pallial commissure (which connects the medial pallium in tetrapods, see below) at the dorsal midline in this group. However, in goldfish, axons arising from the homolog of the medial pallium (ventro-lateral portion of the area dorsalis), cross the midline at more dorsal territories within the anterior commissure than axons from the olfactory pallium (medial portion of the area dorsalis), which decussate more ventrally within the anterior commissure (Northcutt, 2006). Notably, this dorso-ventral parcellation of fibers according to the location of their cell bodies is a feature also present in the telencephalic commissures of tetrapods (see next section). Thus, a topographical arrangement of commissural fibers seems to predate the segregation and emergence of new discrete commissures. In summary, a basic configuration of commissural systems has been conserved since early vertebrates, including the coexistence of homotopic and heterotopic connections within commissural tracts, as well as a spatially segregated arrangement of axons according to their site of origin. Both anatomical features are further evident in the telencephalic commissures of tetrapods.

\section{ORIGIN AND DIVERSIFICATION OF PALLIAL COMMISSURES}

A crucial milestone in vertebrate evolution that resulted in several behavioral and anatomical adaptations, including a significant increase in brain complexity, was the colonization of terrestrial niches by the ancestors of modern tetrapods. In particular, the telencephalic pallium underwent considerable increase in size and number of connections, acquiring further complexity in mammals with the evolution of the six-layered isocortex. Consequently, the telencephalon of tetrapods evolved additional commissures that provide interhemispheric connections between pallial regions. Early neuroanatomists described a distinct commissure in the telencephalon of reptiles, termed the pallial commissure (cpal; Figure 2B, purple; Herrick, 1910; Johnston, 1913). This structure connects mainly the left and right portions of the medial pallium, which in mammals gives rise to the hippocampal formation (Table 1; Voneida and Ebbesson, 1969; Butler, 1976; Kokoros and Northcutt, 1977; Martínez-García et al., 1990; Atoji et al., 2002; Northcutt and Westhoff, 2011). The oldest indication of a distinct pallial commissure in vertebrates comes from the spotted African lungfish, a basal member of the lineage of lobe-finned fish that includes all tetrapods and their common ancestor (Sarcopterygii). In lungfish, the pallial commissure is located immediately rostro-dorsal to the anterior commissure. It differs from the anterior commissure by its medial pallial, as compared to subpallial, bilateral connections (Northcutt and Westhoff, 2011). Similarly, the telencephalic commissures of amphibians include bilateral connections from subpallial and olfactory-recipient nuclei through the anterior commissure, and medial pallial connections through the dorsally-located pallial commissure (Figure 3; Kokoros and Northcutt, 1977; Hofmann and Meyer, 1989; Northcutt and Ronan, 1992). This fiber topography in lungfish and amphibians, along with the axonal parcellation of the anterior commissure of teleost fish, suggest that the evolution of the pallial commissure likely involved a transition from dorsally-fasciculated medial pallial axons within the anterior commissure, to a more defined dorsal segregation of fibers within the rostral tip of the lamina terminalis (see Figures 2B, 3). Accordingly, both commissures arise from the same embryonic territory, the commissural plate (see next section).

Sensory adaptations may also have influenced the evolution and diversification of telencephalic connections, including commissural systems. Colonization of land involved the evolution of aerial respiration and the emergence of an accessory olfactory system specialized in pheromone detection (for a review, see Suárez et al., 2012). In non-mammalian sarcopterygians, efferents from the main and accessory olfactory bulbs decussate through different commissural routes, i.e., the habenular and anterior commissure, respectively (Halpern, 1976; Ulinski and Peterson, 1981; Martinez-Garcia et al., 1991; Scalia et al., 1991; Lohman and Smeets, 1993; Lanuza and Halpern, 1997; Moreno et al., 2005; Patzke et al., 2011; Northcutt and Rink, 2012; Atoji and Wild, 2014), suggesting that the diversification of decussated sensory input to the telencephalon may have also affected the rearrangement of commissural systems. 


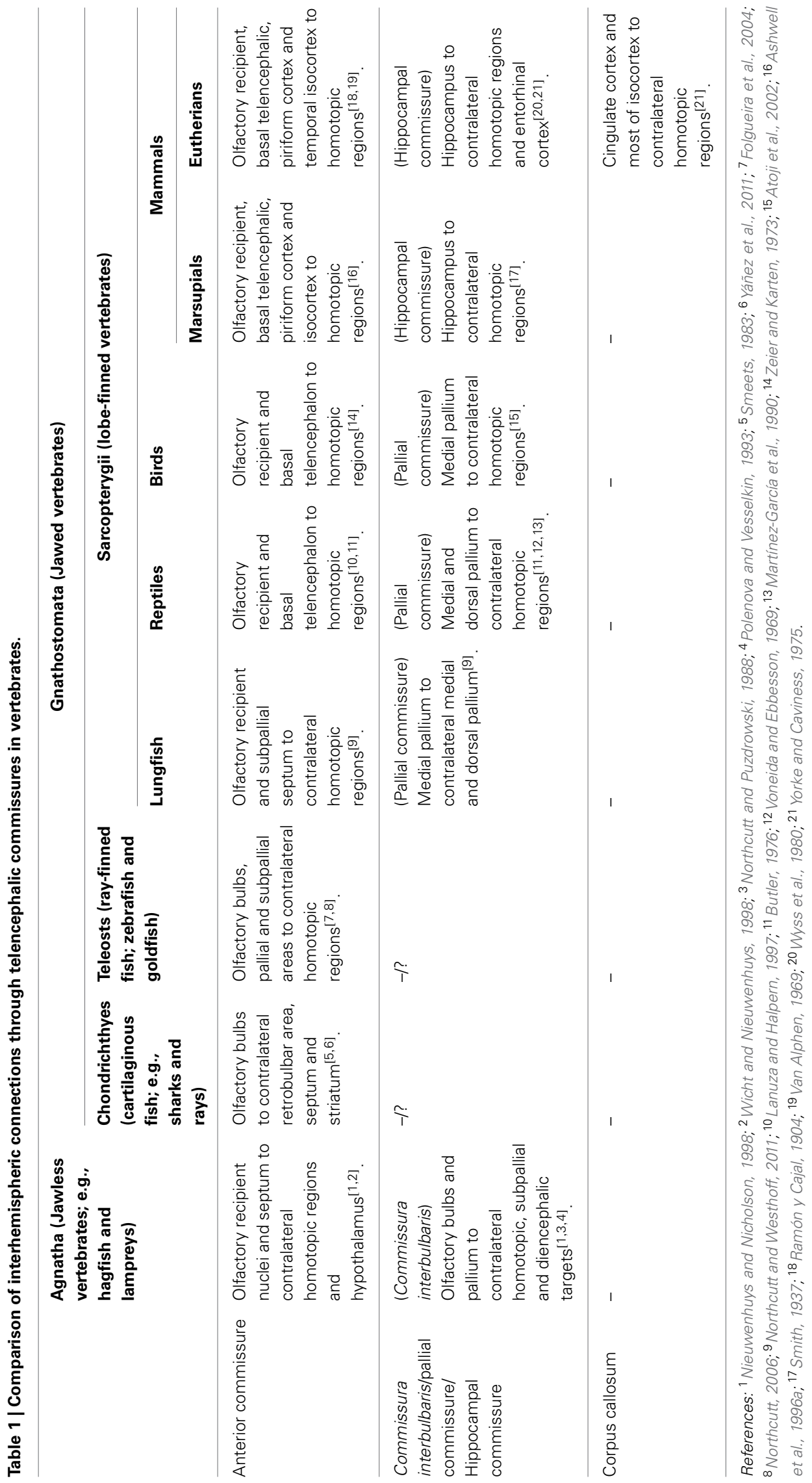




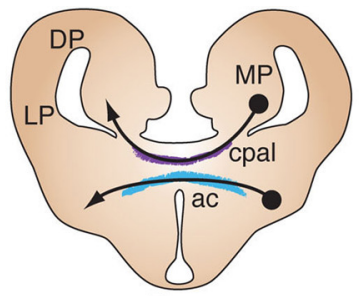

Frog
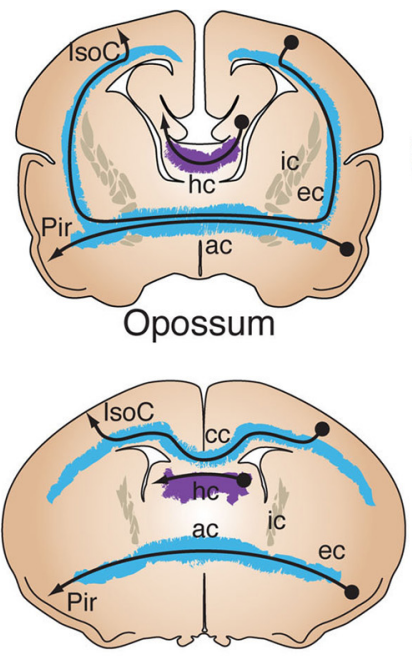

Mouse

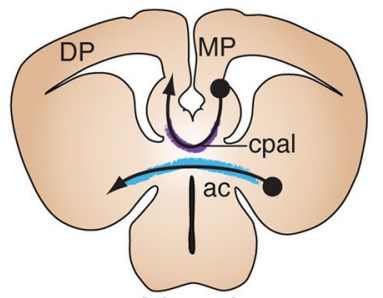

Lizard

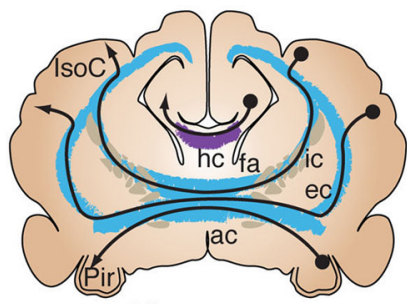

Kangaroo

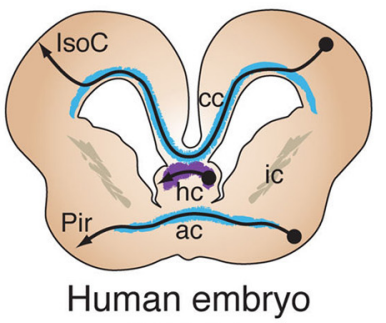

GW 17

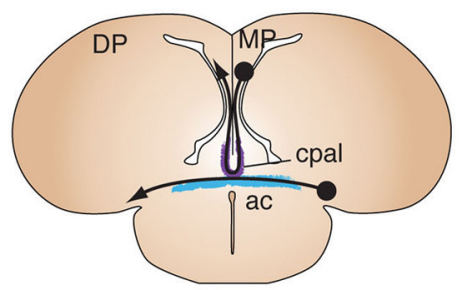

Pigeon

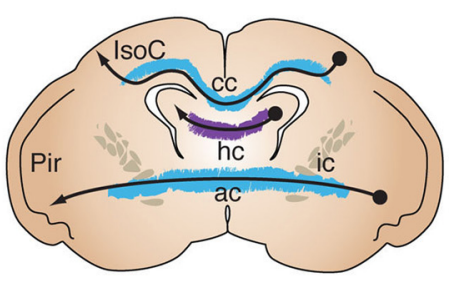

Tenrec

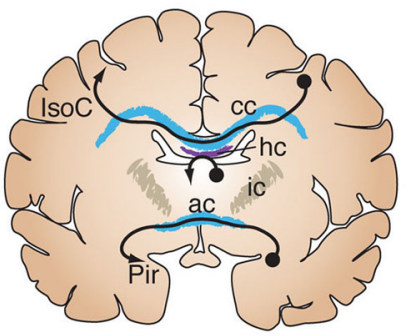

Human adult
FIGURE 3 | Evolution of telencephalic commissures in tetrapods. Coronal schematics of tetrapod brains show the close association between the pallial commissure (cpal) and the anterior commissure (ac), bilaterally connecting the medial pallium (MP) and olfactory recipient structures, respectively. In the opossum all isocortical (IsoC) and piriform (Pir) commissural projections cross through the anterior commissure (ac) after coursing through the external capsule (ec). In the kangaroo, as in other diprotodont marsupials, axons from more dorsal regions of the isocortex course through the internal capsule (ic) toward the anterior commissure, forming the fasciculum aberrans (fa). Hippocampal neurons decussate through the hippocampal commissure (hc). In tenrecs, as in other basal placentals with a small IsoC/Pir ratio, the corpus callosum (cc) is a small structure located immediately above the hippocampal commissure. Developmental studies in mice and humans have shown that all three commissures arise from the commissural plate, forming a single plane of morphogenic patterning. GW, gestational week; DP, dorsal pallium; LP, lateral pallium.
Similar connectivity patterns are found in amniotes, such as reptiles and birds, where the anterior commissure connects mostly subpallial and olfactory-recipient regions from both hemispheres (Zeier and Karten, 1973; Butler, 1976; Lanuza and Halpern, 1997), whereas the pallial commissure carries axons connecting mostly the dorsal septum and topographically arranged fibers of the hippocampus (Table 1; Voneida and Ebbesson, 1969; Butler, 1976; Martínez-García et al., 1990; Atoji et al., 2002). Accordingly, since its discovery the pallial commissure has been considered homologous to the hippocampal commissure of mammals (Figures 2B, 3; Herrick, 1910; Johnston, 1913). In mammals, the pallial commissure has received the names of hippocampal commissure, psalterium and crus (or decussation) of the fornix. It connects mostly homotopic regions of the hippocampus cornu ammonis between hemispheres, as well as heterotopic fibers connecting the hippocampus with the entorhinal cortex (Steward, 1976; Wyss et al., 1980; Voneida et al., 1981; Cui et al., 2013). The evolution of the six-layered isocortex in mammals correlates with a further increase in size and complexity of telencephalic commissures. For example, the corpus callosum, the largest axon tract in the human brain, is a relatively recent evolutionary innovation exclusive to placental mammals. Richard Owen, a prominent anatomist contemporary to Darwin, provided the first comparative study of telencephalic commissures in mammals. He discovered that marsupials lack a corpus callosum, and that their telencephalic commissures include exclusively the hippocampal and anterior commissures, referring to the commissural system of marsupials as "... a structure of brain which is intermediate of that between placental Mammalia and Birds" (Owen, 1837; p. 92). In monotremes and non-diprotodont marsupials all interhemispheric isocortical connections reach the anterior commissure via the external capsule, whereas diprotodont marsupials, such as koalas and kangaroos, possess an additional axonal tract, termed the fasciculus aberrans, that joins the dorsal aspect of the anterior commissure through the internal capsule (Figure 3; Flower, 1865; Smith, 1897, 1902, 1937; Johnston, 1913; Abbie, 1939; Ashwell et al., 1996a). Again, this topographic arrangement of commissural fibers may reflect a common feature of commissural systems. Interestingly, the evolution of the corpus callosum as the main pathway for 
isocortical and cingulate commissural connections in eutherians resulted in the anterior commissure reverting to its ancestral state, i.e., connecting mostly olfactory recipient and subpallial nuclei. Still, some axons from lateral portions of the temporal isocortex decussate via the anterior commissure (Ramón y Cajal, 1904; Horel and Stelzner, 1981; Jouandet and Hartenstein, 1983; Tomasi et al., 2012).

The events that led to the evolution of the mammalian isocortex in general, and eutherian corpus callosum in particular, cannot be fully understood from the fossil record and therefore require comparative developmental and molecular approaches. However, fossil skull endocasts of early ancestors of modern mammals suggest that the primitive mammalian brain was dominated by olfactory structures, including a large piriform cortex, and a small isocortex (Rowe et al., 2011). In modern placental mammals with a small isocortex/piriform cortex ratio, such as hedgehogs (Eulipotyphla), bats (Chiroptera) or tenrecs (Afrosoricida), the corpus callosum is very a small structure located just above the hippocampal commissure (Figure 3), possibly resembling a primitive state of early eutherians (Flower, 1865; Smith, 1897; Abbie, 1939; Krubitzer et al., 1997). Consequently, a larger corpus callosum is found in species with a higher isocortex/piriform cortex ratio, such as rodents and primates (Figures $\mathbf{2 B}, \mathbf{3}$ ), suggesting that isocortical expansion explains the increase of corpus callosum size. The developmental time course of midline crossing of commissural axons in different species may also shed light on the evolution of commissures. For example, in wallabies, the anterior commissure forms first, followed by the fasciculus aberrans and finally the hippocampal commissure, whereas in placental mammals the anterior commissure forms first, followed by the hippocampal commissure and then the corpus callosum (Ashwell et al., 1996b). These developmental sequences suggest that the evolution of the corpus callosum involved a rerouting of dorsal cortical axons, from crossing through the anterior commissure to employing the same embryonic substrate as the hippocampal commissure. Although the developmental events that led to the evolution of the corpus callosum in placental mammals remain largely unknown, the formation of all three commissures in these species depends on the development of the commissural plate (Smith, 1897; Rakic and Yakovlev, 1968; Moldrich et al., 2010). This embryonic structure has been studied in mice and humans (Figures 3, 4), and the molecular and cellular events that characterize its development are discussed below.

\section{MOLECULAR SPECIFICATION OF THE COMMISSURAL PLATE}

As discussed previously, patterning of the telencephalic midline in mouse embryos, including the establishment of dorsoventral territories of commissure formation, is directed by the spatially defined expression of a conserved set of morphogens. The medial pallium/cortical hem expresses Wnt/BMPs, the basal prechordal plate expresses Shh, and the anterior neural ridge, or presumptive commissural plate, expresses Fgfs (Figure 4A; Rubenstein et al., 1998; Campbell, 2003; Hebert and Fishell, 2008; Borello and Pierani, 2010). These morphogens interact via gradients of protein expression, whereby the relative concentration of each morphogen differs at each point of the extracellular space, resulting in either activation or suppression of intracellular effector pathways (Figures $4 \mathbf{A}, \mathbf{B}$ ). In particular, the precise patterning of dorso-ventral domains at the telencephalic midline is critical for the formation of all three telencephalic commissures. Formation of the commissural plate involves the thickening of the lamina terminalis, whereby providing a substrate for convergence and decussation of commissural axons (Figures 4C-F; Rakic and Yakovlev, 1968; Moldrich et al., 2010). From dorsal to ventral, the earliest subdivisions of the commissural plate include the cortical hem/medial pallium, the septum, and the preoptic area, where Wnt/Bmp, Fgf and Shh signaling, respectively, induce formation of these tissues in a concentration-dependent manner (Figure 4D; see for review Rubenstein et al., 1998; Campbell, 2003; Puelles and Rubenstein, 2003; Hebert, 2005; Fernandes and Hebert, 2008; Hebert and Fishell, 2008). The formation of borders within this primordial tissue is primarily controlled by either repressive or inductive mechanisms between individual morphogen signals. For example, studies in mice and chickens have described reciprocal repression between the Bmp/Wnt and Fgf signaling pathways, and between the Bmp/Wnt and Shh signaling pathways (Figure 4E; Lee et al., 2000; Ohkubo et al., 2002; Shimogori et al., 2004; Storm et al., 2006). In contrast, Fgf8 and Shh regulate the expression of one another to maintain normal expression levels, suggesting that a reciprocal inductive mechanism is in place between the septum and preoptic areas (Ohkubo et al., 2002; Storm et al., 2006). This reciprocity between Fgf8 and Shh signaling may be integrated by the transcription factor Six3, as it can directly bind and activate a forebrainspecific Shh enhancer, and can also regulate the expression of Fgf8 prior to telencephalic midline formation (Lagutin et al., 2003; Geng et al., 2008; Jeong et al., 2008). Moreover, following initial telencephalic midline formation, expression of Shh and Fgf8 in the subpallium maintains Six3 expression in the septum and preoptic area (Figure 4E; Storm et al., 2006; Geng et al., 2008). Once morphogenic patterning of the commissural plate has been established, tissue-specific transcription factors further affect cell fate identity, demarcating all three dorso-ventral domains (Figure 4E). First, the medial pallium is defined by expression of transcription factors such as Emx1 and Emx2 (regulated by Wnt signaling), as well as Msx1 and Msx2 (regulated by BMP signaling) (Lee et al., 2000; Hebert et al., 2002, 2003; Shimogori et al., 2004; Fernandes et al., 2007; Caronia et al., 2010). The subpallial septum is defined by the transcription factors Zic2, Vax1, and Lhx5, where ectopic Fgf8 signaling is sufficient to induce their expression, even in the absence of Shh (Okada et al., 2008). Finally, the preoptic area expresses Six3 and Nkx2.1 under control of Shh signaling, which is essential for the formation of the entire subpallium (Figure 4E; Patten and Placzek, 2000; Ohkubo et al., 2002; Corbin et al., 2003; Gunhaga et al., 2003; Nery et al., 2003; Xu et al., 2005, 2008; Gulacsi and Anderson, 2006; Fogarty et al., 2007; Butt et al., 2008; GarciaLopez et al., 2008; Geng et al., 2008; Lavado et al., 2008; Gelman et al., 2009; Hirata et al., 2009; Flandin et al., 2011). Finally, another transcription factor, Gli3, has also been shown to regulate cell-type patterning within the commissural plate (Magnani et al., 2012; Amaniti et al., 2013). Loss of Gli3 affects the expression of BMP/Wnt and Fgf8 at the midline, as well as the expression 

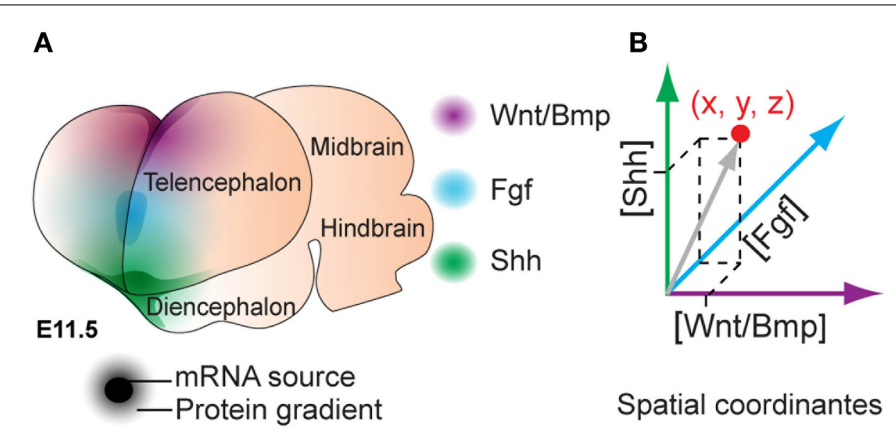

D

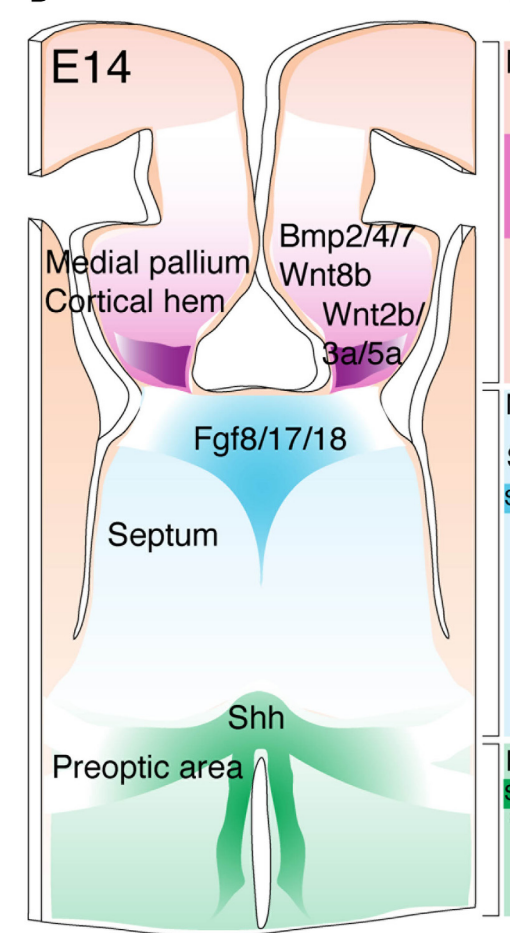

E

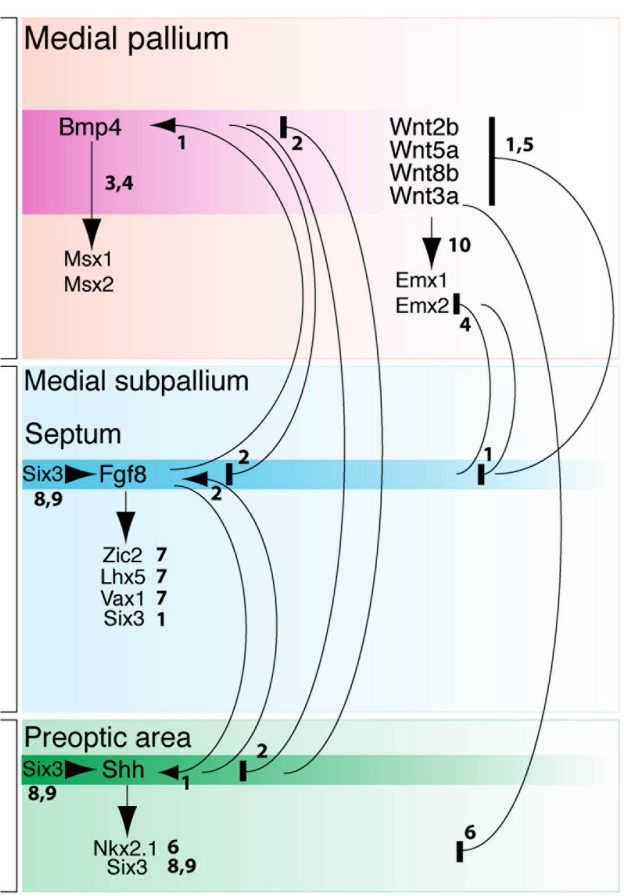

C

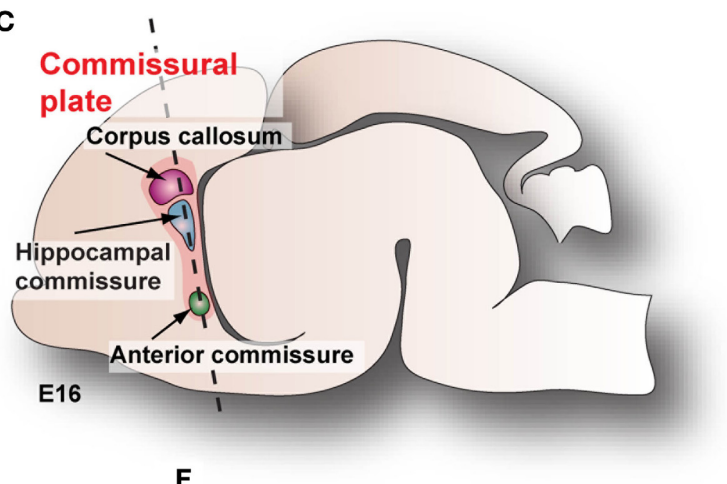

$\mathbf{F}$

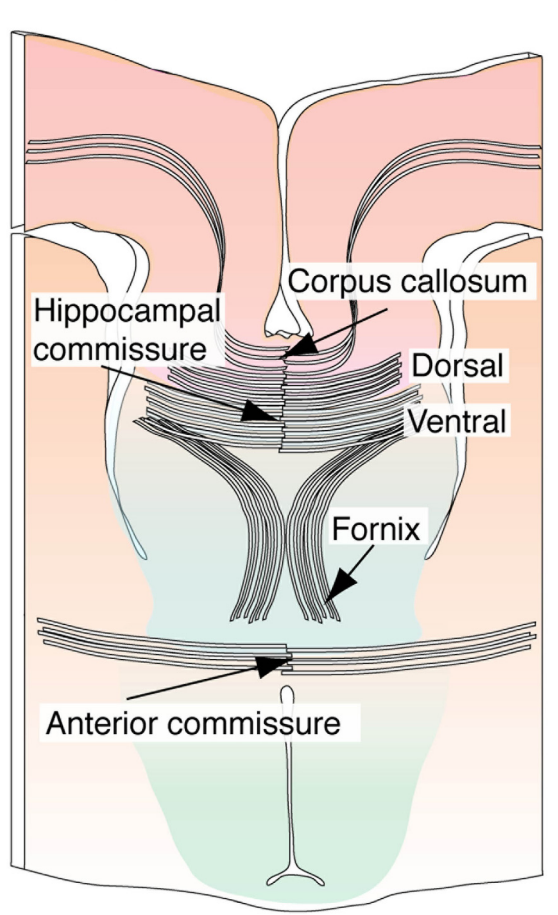

FIGURE 4 | Morphogenic patterning at the commissural plate.

(A) Discrete regions of the early telencephalic midline of mice at $E 11.5$ express diffusible Wnt/Bmp, Fgf, and Shh proteins, as revealed by mRNA expression studies. (B) The differential concentration of each morphogen at any point in space results in distinct intracellular signaling outcomes, generating different cell fates. (C) A midsagittal schematic of the embryonic mouse brain showing the plane of section $(\mathbf{D}, \mathbf{F})$ defined by telencephalic commissures, known as the commissural plate.

(D) Transverse section through the presumptive commissural plate at E14 shows the spatial extent of morphogen expression, mostly defining pallial, septal, and preoptic domains. (E) In general, morphogen interactions are reciprocally repressive between the pallial and subpallial regions; numbers denote references providing evidence for each interaction (see below for reference key). Further definition of the medial pallium, septum and preoptic areas is achieved by the induction of transcription factors such as Msx1/2, Emx1/2 (pallial), Zic2, Lhx5, Vax1 (septal), Six3 and Nkx2.1 (preoptic). (F) Dorso-ventral patterning domains also define the dorso-ventral level at which the three telencephalic commissures will cross within the caudal telencephalic midline. References: ${ }^{1}$ Storm et al., 2006; ${ }^{2}$ Ohkubo et al., 2002; ${ }^{3}$ Fernandes et al., 2007; ${ }^{4}$ Hebert et al., 2003;

${ }^{5}$ Shimogori et al., 2004; ${ }^{6}$ Gunhaga et al., 2003; ${ }^{7}$ Okada et al., $2008 ;{ }^{8} \mathrm{Geng}$ et al., 2008; ${ }^{9}$ Jeong et al., 2008; ${ }^{10}$ Lee et al., 2000. of their downstream effectors, including Emx1 and Emx2 (Theil et al., 1999; Kuschel et al., 2003; Magnani et al., 2012). Although Gli3 is a known downstream effector of Shh signaling, its precise role in the integration of multiple morphogenic signals remains unclear.

Collectively, these genetic patterning studies suggest that initial formation of the commissural plate involves the morphogenic activity of BMP/Wnt and Shh to establish pallial and subpallial territories, respectively, and that the subpallium is then further refined into septal and preoptic regions through Fgf8 signaling. Thus, the specific location through which commissural axons cross the midline depends on the early molecular patterning of the commissural plate, whereby pioneer axons of the corpus callosum cross through the same pallial domain of the dorsal hippocampal commissure, while the ventral hippocampal and anterior commissures form at the septal and preoptic domains, respectively (Figure 4F; Moldrich et al., 2010). Taken together, comparative and molecular data suggest that evolution 
of the corpus callosum involved a rerouting of commissural axons through a preexistent pallial commissural course.

\section{COMMISSURAL AXON GUIDANCE AND CONTRALATERAL TARGETING}

Another important aspect of commissure development that could also account for evolutionary events that led to commissure diversification involves axon guidance and targeting. Following the induction and patterning of the telencephalic midline, growing commissural axons are channeled toward and across the midline by a number of glial cell populations present throughout mammal species (Silver et al., 1982; Cummings et al., 1997; Pires-Neto et al., 1998; Lent et al., 2005). For example, the indusium griseum glia (IGG) and the glial wedge form dorsomedial and ventrolateral boundaries for growing callosal axons, respectively, while the midline zipper glia (MZG) demarcate a ventromedial boundary (Figure 5; Silver et al., 1993; Shu and Richards, 2001; Shu et al., 2003). In mice, glial wedge cells are born around embryonic day (E) 13 and, while retaining their cell bodies in the medial aspect of the lateral ventricle, they extend processes that cluster into a wedge shape that coincides with the boundary between pallial and subpallial domains (cortico-septal boundary, Figure 5A). This cell population, together with the IGG, guide growing axons by expressing chemorepellent molecules such as Slit2, Wnt5a, and Draxin, thus preventing callosal axons from coursing ventrally into septal territory (Shu and Richards, 2001; Keeble et al., 2006; Islam et al., 2009; Unni et al., 2012). By E15, pioneer axons from the cingulate cortex first cross the midline (Koester and O'Leary, 1994; Rash and Richards, 2001), followed by isocortical axons, which fasciculate with them to cross the midline approximately 1 day later (Figures 5A,B). Another cell population that participates in the guidance of callosal axons at the midline is the subcallosal sling (Figure 5C), also referred to as the callosal corridor, a transient neuronal population that lies at the ventral border of the corpus callosum (Silver et al., 1982, 1993; Silver and Ogawa, 1983; Hankin et al., 1988; Shu et al., 2003; Niquille et al., 2009; Benadiba et al., 2012). These cells express Sema3c, which acts as an attractant of pioneer axons from the cingulate cortex through interaction with its receptor Nrp1 (Niquille et al., 2009; Piper et al., 2009).

After crossing the midline, callosal axons grow into the contralateral hemisphere and innervate homotopic (Yorke and Caviness, 1975; Krubitzer et al., 1998; Rash and Richards, 2001; Hofer and Frahm, 2006), and heterotopic regions of the cortex (Boyd et al., 1971; Kretz and Rager, 1990; Aboitiz and Montiel, 2003). Histological studies in mice have revealed a dorso-ventral segregation of callosal axons according to the medio-lateral position of their cell-bodies within the cortex (Richards et al., 2004; Zhou et al., 2013). A similar situation has been described in humans using magnetic resonance imaging, where callosal fibers originating at different medio-lateral positions retain a dorsoventral parcellation within the rostro-caudal axis (Abe et al., 2004; Tovar-Moll et al., 2007; Chao et al., 2009; Fabri et al., 2011; Fabri and Polonara, 2013). Thus, a highly refined topographic organization of axons at the midline is a shared feature of commissural systems. The primary somatosensory and visual cortices of rodents send callosal projections to homotopic and heterotopic

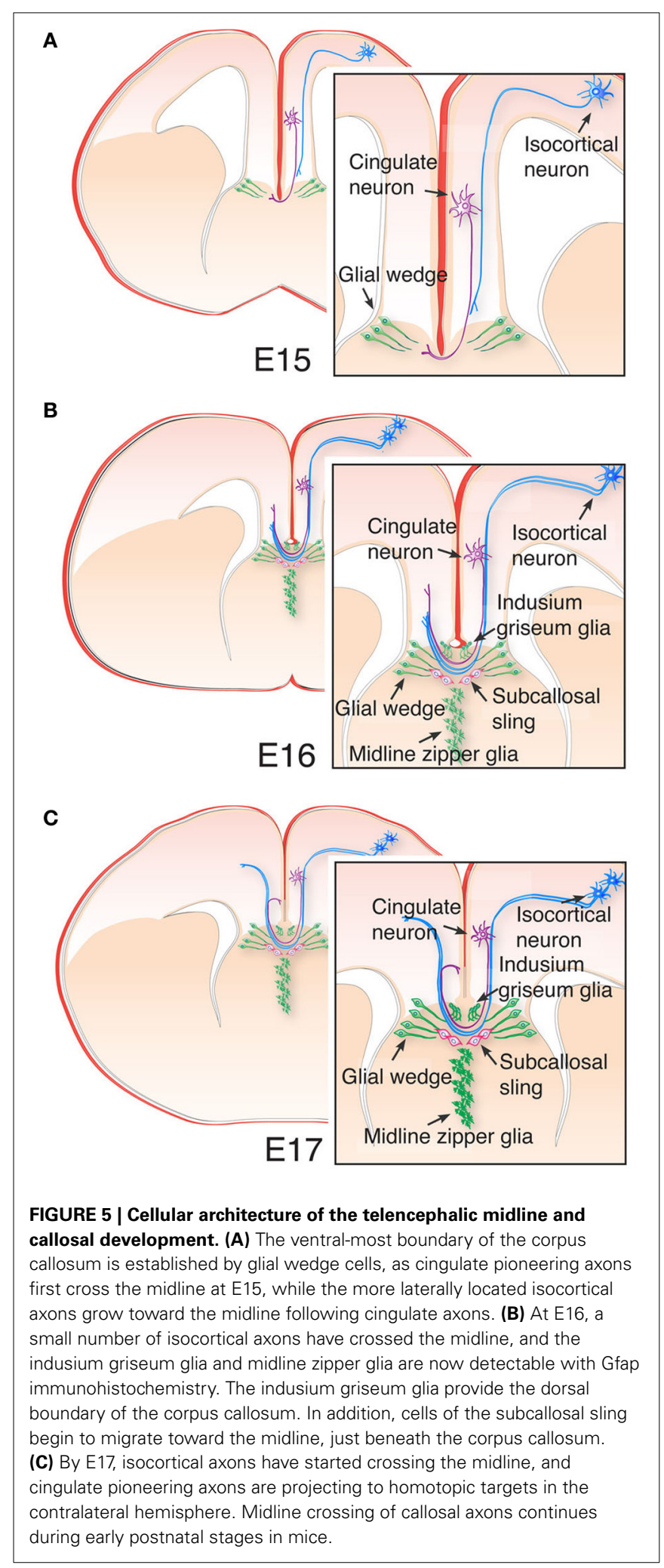

regions, with a distinct axonal arborization at the border between primary and secondary corresponding areas in the contralateral hemisphere (Wise and Jones, 1976; Ivy and Killackey, 1981; Koralek and Killackey, 1990; Mizuno et al., 2007; Wang et al., 
2007). Formation of these contralateral projections occurs mostly during postnatal stages (Wise and Jones, 1976; Wang et al., 2007; Mizuno et al., 2010), and depends on sensory-evoked and spontaneous neural activity during a critical period. Early deprivation of the sensory periphery or thalamic lesions during the first postnatal week in rodents prevents normal development of callosal projections (Innocenti and Frost, 1979; Olavarria et al., 1987; Koralek and Killackey, 1990; Innocenti and Price, 2005). Similarly, disruption of electrical activity directly in callosal neurons results in disrupted contralateral projections (Mizuno et al., 2007, 2010; Wang et al., 2007), suggesting that early experience plays an instructive role in the precise targeting of contralateral axons (Huang et al., 2013; Suárez et al., 2014). Thus, additional developmental processes that may have influenced the origin and diversification of mammalian commissures include precise temporal and spatial interactions between glial cells and neurons, production of axon guidance ligands and expression of receptors, and early spontaneous and sensory-evoked neuronal activity.

\section{CONCLUSION}

In the context of evolution and development of forebrain commissures, a number of brain features can be distinguished as highly conserved throughout vertebrates, the first being a requirement for interhemispheric communication of the two halves of the CNS. The presence of commissural systems throughout bilaterians reflects a computational requirement of interhemispheric coordination for normal behavior. Second, the conservation in vertebrates of a defined set morphogen expression at the telencephalic midline indicates an important developmental event that directs both the identity patterning of brain areas and wiring of commissural axons. Third, another feature of commissural systems shared by vertebrates is the co-occurrence of decussating fibers that project to heterotopic regions with commissural fibers connecting homotopic regions between hemispheres. Moreover, the presence of profuse heterotopic projections in forebrain commissural pathways of early-branched vertebrates suggests that homotopic projections arose as a refinement of the former kind. Finally, a topographical arrangement of axons within the commissural tracts according the place of origin of their cell bodies can also be recognized as a general feature of commissural systems. Moreover, the origin of new commissures, such as the pallial commissure in early tetrapods and the corpus callosum in eutherian mammals, seems to involve the rerouting of a specific population of topographically arranged axons through preexistent commissural substrates. Such examples of axonal rearrangement can be found in congenital cases of callosal malformations in humans (Tovar-Moll et al., 2007, 2014; Wahl et al., 2009).

Although there is currently little evidence to allow speculation about the precise mechanisms that led to the evolution of the corpus callosum in eutherian mammals, an evolutionary developmental approach integrating current gene manipulation techniques in carefully selected animal models may shed light on this fascinating topic.

\section{ACKNOWLEDGMENTS}

The authors would like to thank Rowan Tweedale and Laura Fenlon for helpful comments on the manuscript, and Joy
Schonrock for help obtaining bibliographic material. Research reported in this publication was supported by the National Health and Medical Research Council (NHMRC), Australia, project grants APP1048849 and APP1029975. Linda J. Richards is supported by a Principal Research Fellowship from the NHMRC. The content of this article is solely the responsibility of the authors and does not necessarily represent the official views of the NHMRC.

\section{REFERENCES}

Abbie, A. A. (1939). The origin of the corpus callosum and the fate of the structures related to it. J. Comp. Neurol. 70, 9-44. doi: 10.1002/cne.900700103

Abe, O., Masutani, Y., Aoki, S., Yamasue, H., Yamada, H., Kasai, K., et al. (2004). Topography of the human corpus callosum using diffusion tensor tractography. J. Comput. Assist. Tomogr. 28, 533-539. doi: 10.1097/00004728-20040700000016

Aboitiz, F., and Montiel, J. (2003). One hundred million years of interhemispheric communication: the history of the corpus callosum. Braz. J. Med. Biol. Res. 36, 409-420. doi: 10.1590/S0100-879X2003000400002

Amaniti, E. M., Hasenpusch-Theil, K., Li, Z., Magnani, D., Kessaris, N., Mason, J. O., et al. (2013). Gli3 is required in Emx1+ progenitors for the development of the corpus callosum. Dev. Biol. 376, 113-124. doi: 10.1016/j.ydbio.2013.02.001

Arendt, D., Denes, A. S., Jékely, G., and Tessmar-Raible, K. (2008). The evolution of nervous system centralization. Philos. Trans. R. Soc. B Biol. Sci. 363, 1523-1528. doi: 10.1098/rstb.2007.2242

Ashwell, K. W., Marotte, L. R., Li, L., and Waite, P. M. (1996a). Anterior commissure of the wallaby (Macropus eugenii): adult morphology and development. J. Comp. Neurol. 366, 478-494.

Ashwell, K. W. S., Waite, P. M. E., and Marotte, L. (1996b). Ontogeny of the projection tracts and commissural fibres in the forebrain of the tammar wallaby (Macropus eugenii): timing in comparison with other mammals. Brain Behav. Evol. 47, 8-22.

Assimacopoulos, S., Kao, T., Issa, N. P., and Grove, E. A. (2012). Fibroblast growth factor 8 organizes the neocortical area map and regulates sensory map topography. J. Neurosci. 32, 7191-7201. doi: 10.1523/JNEUROSCI.0071-12.2012

Atoji, Y., and Wild, J. M. (2014). Efferent and afferent connections of the olfactory bulb and prepiriform cortex in the pigeon (Columba livia). J. Comp. Neurol. 522, 1728-1752. doi: 10.1002/cne.23504

Atoji, Y., Wild, J. M., Yamamoto, Y., and Suzuki, Y. (2002). Intratelencephalic connections of the hippocampus in pigeons (Columba livia). J. Comp. Neurol. 447, 177-199. doi: 10.1002/cne.10239

Barreiro-Iglesias, A., Villar-Cheda, B., Abalo, X. M., Anadon, R., and Rodicio, M. C. (2008). The early scaffold of axon tracts in the brain of a primitive vertebrate, the sea lamprey. Brain Res. Bull. 75, 42-52. doi: 10.1016/j.brainresbull.2007.07.020

Benadiba, C., Magnani, D., Niquille, M., Morlé, L., Valloton, D., Nawabi, H., et al. (2012). The ciliogenic transcription factor RFX3 regulates early midline distribution of guidepost neurons required for corpus callosum development. PLoS Genet. 8:e1002606. doi: 10.1371/journal.pgen.1002606

Borello, U., and Pierani, A. (2010). Patterning the cerebral cortex: traveling with morphogens. Curr. Opin. Genet. Dev. 20, 408-415. doi: 10.1016/j.gde.2010.05.003

Boyd, E. H., Pandya, D. N., and Bignall, K. E. (1971). Homotopic and nonhomotopic interhemispheric cortical projections in the squirrel monkey. Exp. Neurol. 32, 256-274. doi: 10.1016/0014-4886(71)90069-0

Brose, K., Bland, K. S., Wang, K. H., Arnott, D., Henzel, W., Goodman, C. S., et al. (1999). Slit proteins bind robo receptors and have an evolutionarily conserved role in repulsive axon guidance. Cell 96, 795-806. doi: 10.1016/S00928674(00)80590-5

Buckles, G. R., Thorpe, C. J., Ramel, M.-C., and Lekven, A. C. (2004). Combinatorial Wnt control of zebrafish midbrain-hindbrain boundary formation. Mech. Dev. 121, 437-447. doi: 10.1016/j.mod.2004.03.026

Butler, A. B. (1976). Telencephalon of the lizard Gekko gecko (Linnaeus): some connections of the cortex and dorsal ventricular ridge. Brain Behav. Evol. 13, 396-417. doi: 10.1159/000123824

Butt, S. J., Sousa, V. H., Fuccillo, M. V., Hjerling-Leffler, J., Miyoshi, G., Kimura, S., et al. (2008). The requirement of $\mathrm{Nkx2-1}$ in the temporal specification of cortical interneuron subtypes. Neuron 59, 722-732. doi: 10.1016/j.neuron.2008.07.031 
Campbell, K. (2003). Dorsal-ventral patterning in the mammalian telencephalon. Curr. Opin. Neurobiol. 13, 50-56. doi: 10.1016/S0959-4388(03)00009-6

Caronia, G., Wilcoxon, J., Feldman, P., and Grove, E. A. (2010). Bone morphogenetic protein signaling in the developing telencephalon controls formation of the hippocampal dentate gyrus and modifies fear-related behavior. J. Neurosci. 30, 6291-6301. doi: 10.1523/JNEUROSCI.0550-10.2010

Chao, Y.-P., Cho, K.-H., Yeh, C.-H., Chou, K.-H., Chen, J.-H., and Lin, C.-P. (2009). Probabilistic topography of human corpus callosum using cytoarchitectural parcellation and high angular resolution diffusion imaging tractography. Hum. Brain Mapp. 30, 3172-3187. doi: 10.1002/hbm.20739

Charron, F., Stein, E., Jeong, J., McMahon, A. P., and Tessier-Lavigne, M. (2003). The morphogen sonic hedgehog is an axonal chemoattractant that collaborates with netrin-1 in midline axon guidance. Cell 113, 11-23. doi: 10.1016/S00928674(03)00199-5

Corbin, J. G., Rutlin, M., Gaiano, N., and Fishell, G. (2003). Combinatorial function of the homeodomain proteins Nkx2.1 and Gsh2 in ventral telencephalic patterning. Development 130, 4895-4906. doi: 10.1242/dev.00717

Cui, Z., Gerfen, C. R., and Young, W. S. (2013). Hypothalamic and other connections with dorsal CA2 area of the mouse hippocampus. J. Comp. Neurol. 521, 1844-1866. doi: 10.1002/cne.23263

Cummings, D. M., Malun, D., and Brunjes, P. C. (1997). Development of the anterior commissure in the opossum: midline extracellular space and glia coincide with early axon decussation. J. Neurobiol. 32, 403-414.

Doldan, M. J., Prego, B., Holmqvist, B., Helvik, J. V., and de Miguel, E. (2000). Emergence of axonal tracts in the developing brain of the turbot (Psetta maxima). Brain Behav. Evol. 56, 300-309. doi: 10.1159/000047214

Evans, T. A., and Bashaw, G. J. (2012). Slit/Robo-mediated axon guidance in Tribolium and Drosophila: divergent genetic programs build insect nervous systems. Dev. Biol. 363, 266-278. doi: 10.1016/j.ydbio.2011.12.046

Fabri, M., and Polonara, G. (2013). Functional topography of human corpus callosum: an fMRI mapping study. Neural Plast. 2013, 1-15. doi: 10.1155/2013/ 251308

Fabri, M., Polonara, G., Mascioli, G., Salvolini, U., and Manzoni, T. (2011). Topographical organization of human corpus callosum: an fMRI mapping study. Brain Res. 1370, 99-111. doi: 10.1016/j.brainres.2010.11.039

Fernandes, M., Gutin, G., Alcorn, H., McConnell, S. K., and Hebert, J. M. (2007). Mutations in the BMP pathway in mice support the existence of two molecular classes of holoprosencephaly. Development 134, 3789-3794. doi: $10.1242 /$ dev.004325

Fernandes, M., and Hebert, J. M. (2008). The ups and downs of holoprosencephaly: dorsal versus ventral patterning forces. Clin. Genet. 73, 413-423. doi: 10.1111/j.1399-0004.2008.00994.x

Flandin, P., Zhao, Y., Vogt, D., Jeong, J., Long, J., Potter, G., et al. (2011). Lhx6 and Lhx8 coordinately induce neuronal expression of Shh that controls the generation of interneuron progenitors. Neuron 70, 939-950. doi: 10.1016/j.neuron.2011.04.020

Flower, W. H. (1865). On the commissures of the cerebral hemispheres of the Marsupialia and Mono-Tremata as compared with those of the placental mammals. Philos. Trans. R. Soc. Lond. B Biol. Sci. 155, 633-651.

Fogarty, M., Grist, M., Gelman, D., Marin, O., Pachnis, V., and Kessaris, N. (2007). Spatial genetic patterning of the embryonic neuroepithelium generates GABAergic interneuron diversity in the adult cortex. J. Neurosci. 27, 10935-10946. doi: 10.1523/JNEUROSCI.1629-07.2007

Folgueira, M., Anadón, R., and Yáñez, J. (2004). Experimental study of the connections of the telencephalon in the rainbow trout (Oncorhynchus mykiss). II: Dorsal area and preoptic region. J. Comp. Neurol. 480, 204-233. doi: $10.1002 /$ cne.20341

Garcia-Lopez, M., Abellan, A., Legaz, I., Rubenstein, J. L., Puelles, L., and Medina, L. (2008). Histogenetic compartments of the mouse centromedial and extended amygdala based on gene expression patterns during development. J. Comp. Neurol. 506, 46-74. doi: 10.1002/cne.21524

Gelman, D. M., Martini, F. J., Nobrega-Pereira, S., Pierani, A., Kessaris, N., and Marin, O. (2009). The embryonic preoptic area is a novel source of cortical GABAergic interneurons. J. Neurosci. 29, 9380-9389. doi: 10.1523/JNEUROSCI.0604-09.2009

Geng, X., Speirs, C., Lagutin, O., Inbal, A., Liu, W., Solnica-Krezel, L., et al. (2008). Haploinsufficiency of Six 3 fails to activate Sonic hedgehog expression in the ventral forebrain and causes holoprosencephaly. Dev. Cell 15, 236-247. doi: 10.1016/j.devcel.2008.07.003
Gulacsi, A., and Anderson, S. A. (2006). Shh maintains Nkx2.1 in the MGE by a Gli3-independent mechanism. Cereb. Cortex 16(Suppl. 1), i89-i95. doi: 10.1093/cercor/bhk018

Gunhaga, L., Marklund, M., Sjodal, M., Hsieh, J. C., Jessell, T. M., and Edlund, T. (2003). Specification of dorsal telencephalic character by sequential Wnt and FGF signaling. Nat. Neurosci. 6, 701-707. doi: 10.1038/nn1068

Halpern, M. (1976). The efferent connections of the olfactory bulb and accessory olfactory bulb in the snakes, Thamnophis sirtalis and Thamnophis radix. J. Morphol. 150(Pt 2), 553-578.

Hankin, M. H., Schneider, B. F., and Silver, J. (1988). Death of the subcallosal glial sling is correlated with formation of the cavum septi pellucidi. J. Comp. Neurol. 272, 191-202. doi: $10.1002 / \mathrm{cne} .902720204$

Hebert, J. M. (2005). Unraveling the molecular pathways that regulate early telencephalon development. Curr. Top. Dev. Biol. 69, 17-37. doi: 10.1016/S00702153(05)69002-3

Hebert, J. M., and Fishell, G. (2008). The genetics of early telencephalon patterning: some assembly required. Nat. Rev. Neurosci. 9, 678-685. doi: 10.1038/ nrn2463

Hebert, J. M., Hayhurst, M., Marks, M. E., Kulessa, H., Hogan, B. L., and McConnell, S. K. (2003). BMP ligands act redundantly to pattern the dorsal telencephalic midline. Genesis 35, 214-219. doi: 10.1002/gene.10183

Hebert, J. M., Mishina, Y., and McConnell, S. K. (2002). BMP signaling is required locally to pattern the dorsal telencephalic midline. Neuron 35, 1029-1041. doi: 10.1016/S0896-6273(02)00900-5

Herrick, C. J. (1910). The morphology of the forebrain in amphibia and reptilia. J. Comp. Neurol. Psychol. 20, 413-547. doi: 10.1002/cne.920200502

Herrick, C. J. (1937). Development of the brain of Amblystoma in early functional stages. J. Comp. Neurol. 67, 381-422.

Hirata, T., Li, P., Lanuza, G. M., Cocas, L. A., Huntsman, M. M., and Corbin, J. G. (2009). Identification of distinct telencephalic progenitor pools for neuronal diversity in the amygdala. Nat. Neurosci. 12, 141-149. doi: 10.1038/nn.2241

Hirth, F., and Reichert, H. (2007). "Basic nervous system types: one or many? Evolution of nervous systems," in A Comprehensive Reference, Vol. 1, ed J. H. Kaas (Academic Press), 55-72.

Hofer, S., and Frahm, J. (2006). Topography of the human corpus callosum revisited - comprehensive fiber tractography using diffusion tensor magnetic resonance imaging. Neuroimage 32, 989-994. doi: 10.1016/j.neuroimage.2006. 05.044

Hofmann, M. H., and Meyer, D. L. (1989). Central projections of the nervus terminalis in four species of amphibians. Brain Behav. Evol. 34, 301-307. doi: $10.1159 / 000116515$

Horel, J. A., and Stelzner, D. J. (1981). Neocortical projections of the rat anterior commissure. Brain Res. 220, 1-12. doi: 10.1016/0006-8993(81)90207-9

Huang, Y., Song, N. N., Lan, W., Zhang, Q., Zhang, L., Zhang, L., et al. (2013). Sensory input is required for callosal axon targeting in the somatosensory cortex. Mol. Brain 6:53. doi: 10.1186/1756-6606-6-53

Innocenti, G. M., and Frost, D. O. (1979). Effects of visual experience on the maturation of the efferent system to the corpus callosum. Nature 280, 231-234. doi: $10.1038 / 280231 \mathrm{a} 0$

Innocenti, G. M., and Price, D. J. (2005). Exuberance in the development of cortical networks. Nat. Rev. Neurosci. 6, 955-965. doi: 10.1038/nrn1790

Islam, S. M., Shinmyo, Y., Okafuji, T., Su, Y., Naser, I. B., Ahmed, G., et al. (2009). Draxin, a repulsive guidance protein for spinal cord and forebrain commissures. Science 323, 388-393. doi: 10.1126/science. 1165187

Ivy, G. O., and Killackey, H. P. (1981). The ontogeny of the distribution of callosal projection neurons in the rat parietal cortex. J. Comp. Neurol. 195, 367-389. doi: 10.1002/cne.901950302

Jeong, Y., Leskow, F. C., El-Jaick, K., Roessler, E., Muenke, M., Yocum, A., et al. (2008). Regulation of a remote Shh forebrain enhancer by the Six 3 homeoprotein. Nat. Genet. 40, 1348-1353. doi: 10.1038/ng.230

Johnston, J. B. (1913). The morphology of the septum, hippocampus, and pallial commissures in repliles and mammals. J. Comp. Neurol. 23, 371-478. doi: $10.1002 /$ cne. 900230502

Jouandet, M. L., and Hartenstein, V. (1983). Basal telencephalic origins of the anterior commissure of the rat. Exp. Brain Res. 50, 183-192.

Keeble, T. R., Halford, M. M., Seaman, C., Kee, N., Macheda, M., Anderson, R. B., et al. (2006). The Wnt receptor Ryk is required for Wnt5a-mediated axon guidance on the contralateral side of the corpus callosum. J. Neurosci. 26, 5840-5848. doi: 10.1523/JNEUROSCI.1175-06.2006 
Koester, S., and O’Leary, D. (1994). Axons of early generated neurons in cingulate cortex pioneer the corpus callosum. J. Neurosci. 14, 6608-6620.

Kokoros, J. J., and Northcutt, R. G. (1977). Telencephalic efferents of the tiger salamander Ambystoma tigrinum tigrinum (Green). J. Comp. Neurol. 173, 613-628. doi: 10.1002/cne.901730402

Koralek, K. A., and Killackey, H. P. (1990). Callosal projections in rat somatosensory cortex are altered by early removal of afferent input. Proc. Natl. Acad. Sci. U.S.A. 87, 1396-1400. doi: 10.1073/pnas.87.4.1396

Kretz, R., and Rager, G. (1990). Reciprocal heterotopic callosal connections between the two striate areas in Tupaia. Exp. Brain Res. 82, 271-278. doi: 10.1007/BF00231247

Krubitzer, L., Clarey, J. C., Tweedale, R., and Calford, M. B. (1998). Interhemispheric connections of somatosensory cortex in the flying fox. J. Comp. Neurol. 402, 538-559.

Krubitzer, L., Künzle, H., and Kaas, J. (1997). Organization of sensory cortex in a Madagascan insectivore, the tenrec (Echinops telfairi). J. Comp. Neurol. 379, 399-414.

Kuratani, S., Horigome, N., Ueki, T., Aizawa, S., and Hirano, S. (1998). Stereotyped axonal bundle formation and neuromeric patterns in embryos of a cyclostome, Lampetra japonica. J. Comp. Neurol. 391, 99-114.

Kuschel, S., Ruther, U., and Theil, T. (2003). A disrupted balance between Bmp/Wnt and Fgf signaling underlies the ventralization of the Gli3 mutant telencephalon. Dev. Biol. 260, 484-495. doi: 10.1016/S0012-1606(03)00252-5

Lagutin, O. V., Zhu, C. C., Kobayashi, D., Topczewski, J., Shimamura, K., Puelles, L., et al. (2003). Six3 repression of Wnt signaling in the anterior neuroectoderm is essential for vertebrate forebrain development. Genes Dev. 17, 368-379. doi: $10.1101 /$ gad.1059403

Lanuza, E., and Halpern, M. (1997). Afferent and efferent connections of the nucleus sphericus in the snake Thamnophis sirtalis: convergence of olfactory and vomeronasal information in the lateral cortex and the amygdala. J. Comp. Neurol. 385, 627-640.

Lavado, A., Lagutin, O. V., and Oliver, G. (2008). Six3 inactivation causes progressive caudalization and aberrant patterning of the mammalian diencephalon. Development 135, 441-450. doi: 10.1242/dev.010082

Lee, S. M., Tole, S., Grove, E., and McMahon, A. P. (2000). A local Wnt-3a signal is required for development of the mammalian hippocampus. Development 127 , 457-467.

Lent, R., Uziel, D., Baudrimont, M., and Fallet, C. (2005). Cellular and molecular tunnels surrounding the forebrain commissures of human fetuses. J. Comp. Neurol. 483, 375-382. doi: 10.1002/cne.20427

Lohman, A. H., and Smeets, W. J. (1993). Overview of the main and accessory olfactory bulb projections in reptiles. Brain Behav. Evol. 41, 147-155.

Magnani, D., Hasenpusch-Theil, K., and Theil, T. (2012). Gli3 controls subplate formation and growth of cortical axons. Cereb. Cortex 23, 2542-2551. doi: $10.1093 /$ cercor/bhs 237

Martínez-García, F., Amiguet, M., Schwerdtfeger, W. K., Olucha, F. E., and Lorente, M. J. (1990). Interhemispheric connections through the pallial commissures in the brain of Podarcis hispanica and Gallotia stehlinii (Reptilia, Lacertidae). J. Morphol. 205, 17-31. doi: 10.1002/jmor.1052050104

Martinez-Garcia, F., Olucha, F. E., Teruel, V., Lorente, M. J., and Schwerdtfeger, W. K. (1991). Afferent and efferent connections of the olfactory bulbs in the lizard Podarcis hispanica. J. Comp. Neurol. 305, 337-347. doi: 10.1002/cne.903050214

Meek, J., and Nieuwenhuys, R. (1998). "Holosteans and teleosts," The Central Nervous System of Vertebrates, Vol. 2, eds R. Nieuwenhuys, H. Ten Donkelaar, and C. Nicholson (Berlin: Springer), 759-937.

Mizuno, H., Hirano, T., and Tagawa, Y. (2007). Evidence for activity-dependent cortical wiring: formation of interhemispheric connections in neonatal mouse visual cortex requires projection neuron activity. J. Neurosci. 27, 6760-6770. doi: 10.1523/JNEUROSCI.1215-07.2007

Mizuno, H., Hirano, T., and Tagawa, Y. (2010). Pre-synaptic and post-synaptic neuronal activity supports the axon development of callosal projection neurons during different post-natal periods in the mouse cerebral cortex. Eur. J. Neurosci. 31, 410-424. doi: 10.1111/j.1460-9568.2009.07070.x

Moldrich, R. X., Gobius, I., Pollak, T., Zhang, J., Ren, T., Brown, L., et al. (2010). Molecular regulation of the developing commissural plate. J. Comp. Neurol. 518 , 3645-3661. doi: 10.1002/cne.22445

Moreno, N., Morona, R., López, J. M., Muñoz, M., and González, A. (2005). Lateral and medial amygdala of anuran amphibians and their relation to olfactory and vomeronasal information. Brain Res. Bull. 66, 332-336. doi: 10.1016/j.brainresbull.2005.05.017

Nery, S., Corbin, J. G., and Fishell, G. (2003). Dlx2 progenitor migration in wild type and Nkx2.1 mutant telencephalon. Cereb. Cortex 13, 895-903. doi: $10.1093 /$ cercor/13.9.895

Nieuwenhuys, R. (2009). The forebrain of actinopterygians revisited. Brain Behav. Evol. 73, 229-252. doi: 10.1159/000225622

Nieuwenhuys, R., and Nicholson, C. (1998). "Lampreys, Petromyzontoidea," in The Central Nervous System of Vertebrates, Vol. 1, eds R. Nieuwenhuys, H. Ten Donkelaar, and C. Nicholson (Berlin: Springer), 397-495.

Niquille, M., Garel, S., Mann, F., Hornung, J.-P., Otsmane, B., Chevalley, S., et al. (2009). Transient neuronal populations are required to guide callosal axons: a role for semaphorin 3C. PLoS Biol. 7:e1000230. doi: 10.1371/journal.pbio. 1000230

Northcutt, R. G. (2006). Connections of the lateral and medial divisions of the goldfish telencephalic pallium. J. Comp. Neurol. 494, 903-943. doi: $10.1002 / \mathrm{cne} .20853$

Northcutt, R. G. (2008). Forebrain evolution in bony fishes. Brain Res. Bull. 75, 191-205. doi: 10.1016/j.brainresbull.2007.10.058

Northcutt, R. G. (2011). Olfactory projections in the white sturgeon, Acipenser transmontanus: an experimental study. J. Comp. Neurol. 519, 1999-2022. doi: $10.1002 /$ cne. 22619

Northcutt, R. G., and Puzdrowski, R. L. (1988). Projections of the olfactory bulb and nervus terminalis in the silver lamprey. Brain Behav. Evol. 32, 96-107. doi: $10.1159 / 000116537$

Northcutt, R. G., and Rink, E. (2012). Olfactory projections in the lepidosirenid lungfishes. Brain Behav. Evol. 79, 4-25. doi: 10.1159/000331267

Northcutt, R. G., and Ronan, M. (1992). Afferent and efferent connections of the bullfrog medial pallium. Brain Behav. Evol. 40, 1-16. doi: 10.1159/000113898

Northcutt, R. G., and Westhoff, G. (2011). Connections of the medial telencephalic wall in the spotted African Lungfish. Brain Behav. Evol. 77, 14-32. doi: $10.1159 / 000322549$

O'Leary, D. D., Chou, S. J., and Sahara, S. (2007). Area patterning of the mammalian cortex. Neuron 56, 252-269. doi: 10.1016/j.neuron.2007.10.010

Ohkubo, Y., Chiang, C., and Rubenstein, J. L. (2002). Coordinate regulation and synergistic actions of BMP4, SHH and FGF8 in the rostral prosencephalon regulate morphogenesis of the telencephalic and optic vesicles. Neuroscience 111, 1-17. doi: 10.1016/S0306-4522(01)00616-9

Okada, T., Okumura, Y., Motoyama, J., and Ogawa, M. (2008). FGF8 signaling patterns the telencephalic midline by regulating putative key factors of midline development. Dev. Biol. 320, 92-101. doi: 10.1016/j.ydbio.2008.04.034

Olavarria, J., Malach, R., and Van sluyters, R. C. (1987). Development of visual callosal connections in neonatally enucleated rats. J. Comp. Neurol. 260, 321-348. doi: $10.1002 /$ cne.902600302

Owen, R. (1837). On the structure of the brain in marsupial animals. Philos. Trans. R. Soc. Lond. B Biol. Sci. 127, 87-96.

Pani, A. M., Mullarkey, E. E., Aronowicz, J., Assimacopoulos, S., Grove, E. A., and Lowe, C. J. (2012). Ancient deuterostome origins of vertebrate brain signalling centres. Nature 483, 289-294. doi: 10.1038/nature10838

Patten, I., and Placzek, M. (2000). The role of Sonic hedgehog in neural tube patterning. Cell. Mol. Life Sci. 57, 1695-1708. doi: 10.1007/PL00000652

Patzke, N., Manns, M., and Güntürkün, O. (2011). Telencephalic organization of the olfactory system in homing pigeons (Columba livia). Neuroscience 194, 53-61. doi: 10.1016/j.neuroscience.2011.08.001

Paul, L. K., Brown, W. S., Adolphs, R., Tyszka, J. M., Richards, L. J., Mukherjee, P., et al. (2007). Agenesis of the corpus callosum: genetic, developmental and functional aspects of connectivity. Nat. Rev. Neurosci. 8, 287-299. doi: $10.1038 / \mathrm{nrn} 2107$

Piper, M., Plachez, C., Zalucki, O., Fothergill, T., Goudreau, G., Erzurumlu, R., et al. (2009). Neuropilin 1-Sema signaling regulates crossing of cingulate pioneering axons during development of the corpus callosum. Cereb. Cortex 19(Suppl. 1), i11-i21. doi: 10.1093/cercor/bhp027

Pires-Neto, M. A., Braga-De-Souza, S., and Lent, R. (1998). Molecular tunnels and boundaries for growing axons in the anterior commissure of hamster embryos. J. Comp. Neurol. 399, 176-188.

Polenova, O. A., and Vesselkin, N. P. (1993). Olfactory and nonolfactory projections in the river lamprey (Lampetra fluviatilis) telencephalon. J. Hirnforsch. 34, 261-279. 
Pombal, M. A., Megías, M., Bardet, S. M., and Puelles, L. (2009). New and Old thoughts on the segmental organization of the forebrain in lampreys. Brain Behav. Evol. 74, 7-19. doi: 10.1159/000229009

Puelles, L., and Rubenstein, J. L. (2003). Forebrain gene expression domains and the evolving prosomeric model. Trends Neurosci. 26, 469-476. doi: 10.1016/S01662236(03)00234-0

Rakic, P., and Yakovlev, P. I. (1968). Development of the corpus callosum and cavum septi in man. J. Comp. Neurol. 132, 45-72. doi: 10.1002/cne.901320103

Ramón y Cajal, S. (1904). Histology of the Nervous System of Man and Vertebrates. New York, NY: Oxford University Press.

Rash, B. G., and Grove, E. A. (2011). Shh and Gli3 regulate formation of the telencephalic-diencephalic junction and suppress an isthmuslike signaling source in the forebrain. Dev. Biol. 359, 242-250. doi: 10.1016/j.ydbio.2011.08.026

Rash, B. G., and Richards, L. J. (2001). A role for cingulate pioneering axons in the development of the corpus callosum. J. Comp. Neurol. 434, 147-157. doi: $10.1002 / \mathrm{cne} .1170$

Rétaux, S., and Kano, S. (2010). Midline signaling and evolution of the forebrain in chordates: a focus on the lamprey hedgehog case. Integr. Comp. Biol. 50, 98-109. doi: 10.1093/icb/icq032

Richards, L. J., Plachez, C., and Ren, T. (2004). Mechanisms regulating the development of the corpus callosum and its agenesis in mouse and human. Clin. Genet. 66, 276-289. doi: 10.1111/j.1399-0004.2004.00354.x

Round, J., and Stein, E. (2007). Netrin signaling leading to directed growth cone steering. Curr. Opin. Neurobiol. 17, 15-21. doi: 10.1016/j.conb.2007.01.003

Rowe, T. B., Macrini, T. E., and Luo, Z. X. (2011). Fossil evidence on origin of the mammalian brain. Science 332, 955-957. doi: 10.1126/science.1203117

Rubenstein, J. L., Shimamura, K., Martinez, S., and Puelles, L. (1998). Regionalization of the prosencephalic neural plate. Annu. Rev. Neurosci. 21, 445-477.

Scalia, F., Gallousis, G., and Roca, S. (1991). Differential projections of the main and accessory olfactory bulb in the frog. J. Comp. Neurol. 305, 443-461. doi: 10.1002/cne.903050308

Semmler, H., Chiodin, M., Bailly, X., Martinez, P., and Wanninger, A. (2010). Steps towards a centralized nervous system in basal bilaterians: insights from neurogenesis of the acoel Symsagittifera roscoffensis. Dev. Growth Differ. 52, 701-713. doi: 10.1111/j.1440-169X.2010.01207.x

Shimogori, T., Banuchi, V., Ng, H. Y., Strauss, J. B., and Grove, E. A. (2004). Embryonic signaling centers expressing BMP, WNT and FGF proteins interact to pattern the cerebral cortex. Development 131, 5639-5647. doi: 10.1242/dev.01428

Shimogori, T., and Grove, E. A. (2005). Fibroblast growth factor 8 regulates neocortical guidance of area-specific thalamic innervation. J. Neurosci. 25, 6550-6560. doi: 10.1523/JNEUROSCI.0453-05.2005

Shu, T., Li, Y., Keller, A., and Richards, L. J. (2003). The glial sling is a migratory population of developing neurons. Development 130, 2929-2937. doi: 10.1242/dev.00514

Shu, T., and Richards, L. J. (2001). Cortical axon guidance by the glial wedge during the development of the corpus callosum. J. Neurosci. 21, 2749-2758.

Silver, J., Edwards, M. A., and Levitt, P. (1993). Immunocytochemical demonstration of early appearing astroglial structures that form boundaries and pathways along axon tracts in the fetal brain. J. Comp. Neurol. 328, 415-436. doi: $10.1002 /$ cne. 903280308

Silver, J., Lorenz, S. E., Wahlsten, D., and Coughlin, J. (1982). Axonal guidance during development of the great cerebral commissures: descriptive and experimental studies, in vivo, on the role of preformed glial pathways. J. Comp. Neurol. 210, 10-29. doi: 10.1002/cne.902100103

Silver, J., and Ogawa, M. Y. (1983). Postnatally induced formation of the corpus callosum in acallosal mice on glia-coated cellulose bridges. Science 220, 1067-1069. doi: $10.1126 /$ science. 6844928

Smeets, W. J. A. J. (1983). The secondary olfactory connections in two chondrichthians, the shark Scyliorhinus canicula and the ray Raja clavata. J. Comp. Neurol. 218, 334-344. doi: 10.1002/cne.902180309

Smeets, W. J. A. J. (1998). “Cartlaginous fishes," in The Central Nervous System of Vertebrates, Vol. 1, eds R. Nieuwenhuys, H. Ten Donkelaar, and C. Nicholson (Berlin: Springer), 552-654.

Smith, G. E. (1897). The origin of the corpus callosum: a comparative study of the hippocampal region of the cerebrum of Marsupialia and certain cheiroptera. Trans. Linn. Soc. Lond. 2nd Ser. Zool. 7, 47-69. doi: 10.1111/j.10963642.1897.tb00401a.x

Smith, G. E. (1902). On a peculiarity of the cerebral commissures in certain Marsupialia, not hitherto recognised as a distinctive feature of the Diprotodontia. Proc. R. Soc. Lond. 70, 226-231.

Smith, G. E. (1937). A preliminary communication upon the cerebral commissures of the Mammalia, with special reference to the Monotremata and Marsupialia. J. Anat. 71, 528-543.

Steward, O. (1976). Topographic organization of the projections from the entorhinal area to the hippocampal formation of the rat. J. Comp. Neurol. 167, 285-314. doi: 10.1002/cne.901670303

Storm, E. E., Garel, S., Borello, U., Hebert, J. M., Martinez, S., McConnell, S. K., et al. (2006). Dose-dependent functions of Fgf8 in regulating telencephalic patterning centers. Development 133, 1831-1844. doi: 10.1242/dev.02324

Suárez, R., Fenlon, L. R., Marek, R., Avitan, L., Sah, P., Goodhill, G. J., et al. (2014). Balanced interhemispheric cortical activity is required for correct targeting of the corpus callosum. Neuron 82, 1289-1298. doi: 10.1016/j.neuron.2014.04.040

Suárez, R., García-González, D., and de Castro, F. (2012). Mutual influences between the main olfactory and vomeronasal systems in development and evolution. Front. Neuroanat. 6:50. doi: 10.3389/fnana.2012.00050

Sugahara, F., Murakami, Y., Adachi, N., and Kuratani, S. (2013). Evolution of the regionalization and patterning of the vertebrate telencephalon: what can we learn from cyclostomes? Curr. Opin. Genet. Dev. 23, 475-483. doi: 10.1016/j.gde.2013.02.008

Theil, T., Alvarez-Bolado, G., Walter, A., and Rüther, U. (1999). Gli3 is required for Emx gene expression during dorsal telencephalon development. Development 126, 3561-3571.

Tole, S., Gutin, G., Bhatnagar, L., Remedios, R., and Hébert, J. M. (2006). Development of midline cell types and commissural axon tracts requires Fgfr 1 in the cerebrum. Dev. Biol. 289, 141-151. doi: 10.1016/j.ydbio.2005.10.020

Tomasi, S., Caminiti, R., and Innocenti, G. M. (2012). Areal differences in diameter and length of corticofugal projections. Cereb. Cortex 22, 1463-1472. doi: $10.1093 /$ cercor/bhs011

Tovar-Moll, F., Moll, J., de Oliveira-Souza, R., Bramati, I., Andreiuolo, P. A., and Lent, R. (2007). Neuroplasticity in human callosal dysgenesis: a diffusion tensor imaging study. Cereb. Cortex 17, 531-541. doi: 10.1093/cercor/bhj178

Tovar-Moll, F., Monteiro, M., Andrade, J., Bramati, I. E., Vianna-Barbosa, R., Marins, T., et al. (2014). Structural and functional brain rewiring clarifies preserved interhemispheric transfer in humans born without the corpus callosum. Proc. Natl. Acad. Sci. U.S.A. 111, 7843-7848. doi: 10.1073/pnas.1400806111

Toyama, R., Kim, M. H., Rebbert, M. L., Gonzales, J., Burgess, H., and Dawid, I. B. (2013). Habenular commissure formation in zebrafish is regulated by the pineal gland-specific gene unc119c. Dev. Dyn. 242, 1033-1042. doi: 10.1002/dvdy.23994

Ulinski, P. S., and Peterson, E. H. (1981). Patterns of olfactory projections in the desert iguana, Dipsosaurus dorsalis. J. Morphol. 168, 189-227. doi: 10.1002/jmor.1051680208

Unni, D. K., Piper, M., Moldrich, R. X., Gobius, I., Liu, S., Fothergill, T., et al. (2012). Multiple Slits regulate the development of midline glial populations and the corpus callosum. Dev. Biol. 365, 36-49. doi: 10.1016/j.ydbio.2012. 02.004

Van Alphen, H. A. (1969). The anterior commissure of the rabbit: a descriptive and experimental anatomical study with an atlas of the rabbit telencephalon in horizontal sections. Acta Anat. 74, 1-112.

Voneida, T. J., and Ebbesson, S. O. E. (1969). On the origin and distribution of axons in the pallial commissures in the tegu lizard (Tupinambis nigropunctatus). Brain Behav. Evol. 2, 467-481.

Voneida, T. J., Vardaris, R. M., Fish, S. E., and Reiheld, C. T. (1981). The origin of the hippocampal commissure in the rat. Anat. Rec. 201, 91-103. doi: 10.1002/ar.1092010112

Wahl, M., Strominger, Z., Jeremy, R. J., Barkovich, A. J., Wakahiro, M., Sherr, E. H., et al. (2009). Variability of homotopic and heterotopic callosal connectivity in partial agenesis of the corpus callosum: A 3T diffusion tensor imaging and Q-ball tractography study. Am. J. Neuroradiol. 30, 282-289. doi: 10.3174/ajnr.A1361

Walshe, J., and Mason, I. (2003). Unique and combinatorial functions of Fgf3 and Fgf8 during zebrafish forebrain development. Development 130, 4337-4349. doi: $10.1242 /$ dev.00660 
Wang, C.-L., Zhang, L., Zhou, Y., Zhou, J., Yang, X.-J., Duan, S.-M., et al. (2007). Activity-dependent development of callosal projections in the somatosensory cortex. J. Neurosci. 27, 11334-11342. doi: 10.1523/JNEUROSCI.3380-07.2007

Wicht, H., and Nieuwenhuys, R. (1998). "Hagfishes (Myxinoidea)," in The Central Nervous System of Vertebrates, Vol. 1, eds R. Nieuwenhuys, H. Ten Donkelaar, and C. Nicholson (Berlin: Springer), 497-549.

Wicht, H., and Northcutt, R. G. (1992). The forebrain of the Pacific hagfish: a cladistic reconstruction of the ancestral craniate forebrain. Brain Behav. Evol. 40, 25-64.

Wicht, H., and Northcutt, R. G. (1998). Telencephalic connections in the pacific hagfish (Eptatretus stouti), with special reference to the thalamopallial system. J. Comp. Neurol. 395, 245-260.

Wilson, S. W., and Houart, C. (2004). Early steps in the development of the forebrain. Dev. Cell 6, 167-181. doi: 10.1016/S1534-5807(04)00027-9

Wise, S. P., and Jones, E. G. (1976). The organization and postnatal development of the commissural projection of the rat somatic sensory cortex. J. Comp. Neurol. 168, 313-343. doi: 10.1002/cne.901680302

Wyss, J. M., Swanson, L. W., and Cowan, W. M. (1980). The organization of the fimbria, dorsal fornix and ventral hippocampal commissure in the rat. Anat. Embryol. 158, 303-316. doi: 10.1007/BF00301819

$\mathrm{Xu}$, Q., Tam, M., and Anderson, S. A. (2008). Fate mapping Nkx2.1-lineage cells in the mouse telencephalon. J. Comp. Neurol. 506, 16-29. doi: 10.1002/cne.21529

$\mathrm{Xu}$, Q., Wonders, C. P., and Anderson, S. A. (2005). Sonic hedgehog maintains the identity of cortical interneuron progenitors in the ventral telencephalon. Development 132, 4987-4998. doi: 10.1242/dev.02090

Yáñez, J., Folgueira, M., Köhler, E., Martínez, C., and Anadón, R. (2011). Connections of the terminal nerve and the olfactory system in two galeomorph sharks: an experimental study using a carbocyanine dye. J. Comp. Neurol. 519, 3202-3217.
Yorke, C. H., and Caviness, V. S. (1975). Interhemispheric neocortical connections of the corpus callosum in the normal mouse: a study based on anterograde and retrograde methods. J. Comp. Neurol. 164, 233-245. doi: $10.1002 / \mathrm{cne} .901640206$

Zeier, H. J., and Karten, H. J. (1973). Connections of the anterior commissure in the pigeon (Columba livia). J. Comp. Neurol. 150, 201-216. doi: $10.1002 /$ cne. 901500207

Zhou, J., Wen, Y., She, L., Sui, Y. N., Liu, L., Richards, L. J., et al. (2013). Axon position within the corpus callosum determines contralateral cortical projection. Proc. Natl. Acad. Sci. U.S.A. 110, E2714-E2723. doi: 10.1073/pnas.13102 33110

Zou, Y., and Lyuksyutova, A. I. (2007). Morphogens as conserved axon guidance cues. Curr. Opin. Neurobiol. 17, 22-28. doi: 10.1016/j.conb.2007.01.006

Conflict of Interest Statement: The authors declare that the research was conducted in the absence of any commercial or financial relationships that could be construed as a potential conflict of interest.

Received: 06 December 2013; accepted: 19 June 2014; published online: 14 July 2014. Citation: Suárez R, Gobius I and Richards LJ (2014) Evolution and development of interhemispheric connections in the vertebrate forebrain. Front. Hum. Neurosci. 8:497. doi: 10.3389/fnhum.2014.00497

This article was submitted to the journal Frontiers in Human Neuroscience.

Copyright (c) 2014 Suárez, Gobius and Richards. This is an open-access article distributed under the terms of the Creative Commons Attribution License (CC BY). The use, distribution or reproduction in other forums is permitted, provided the original author(s) or licensor are credited and that the original publication in this journal is cited, in accordance with accepted academic practice. No use, distribution or reproduction is permitted which does not comply with these terms. 